\section{All the Places.}

Musawenkosi Khanyile.

Cape Town: uHlanga, 2019. 55pp.

ISBN 9780620838719.

As the title indicates, Musawenkosi Khanyile's debut collection is preoccupied with place and space. A grainy black and white cover photograph captures a lone figure as he traverses a bare landscape towards a smattering of buildings hunched together in the middle distance, where the flat horizon bisects a sky the colour of bleached bone. This image captures the mood and highlights the themes of the collection. The blurb describes the work as a "poetic Bildungsroman" that unfolds as a series of snapshots and memories. The single narrator takes the reader on a linear journey through the "rural", "township" and "urban" spaces of his childhood and youth. These geospatial divisions signal the movements and developments in the speaker's life, and thus foreground the important connection between place and memory. The collection itself is organised along these same divisions.
The first poem, "A School Visit" (9), in the "Rural" section, introduces most of the primary themes and preoccupations of the collection. The speaker describes in first-person a visit that he makes to a school where every class "had a window with a hole in it, / a broken desk, / and something wrong with the door". Holes in walls, windows and clothes, broken desks and beds, and doors that cannot shut properly are images that repeat in many of the poems and link to the themes of poverty, distance and lack that the cover photo evokes so effectively.

When the speaker is introduced to the children as "an important guest", he states that he "tried to put on the face of someone who has figured out this life thing, / attempting the walk of those who know where their lives are going". This comment introduces a recurring concern in the collection, namely the disjuncture between what the speaker feels himself to be, and what he perceives as the expectations of others.

The poem continues to recount how the speaker "took the exercise book of a little girl / who smelled of paraffin and looked at the tree she had drawn- / a leafless tree with no bird in it". The barrenness of the tree reinforces the impression of an environment in which nothing can thrive, and thus offsets the pathos of the final stanza: "She said Doctor, spitting out saliva, / when I asked her what she wanted to be when she grew up" (emphasis in original). The discrepancy between the child's apparently hopeless environment and her hope of becoming a doctor is rendered sharply poignant by the fact that Khanyile, who grew up in the township of Nseleni in Kwa-Zulu Natal, holds a Master's degree in Clinical Psychology from the University of Zululand and works as a student counsellor at the University of Cape Town, where he is pursuing an MA in Public Health. He thus represents those like the little girl in the poem, whose dreams are bigger than their circumstances.

The work is boldly autobiographical: it is dedicated to "Zamo, my brother", and two of the poems in the collection are also addressed to Zamo. The second poem, "The World Opens Up" (48-9), is found in the "Urban" section, and speaks of the township as a place where people are "walled in", where you have to "carve your way out / like a prisoner committed to an escape plan". The speaker is "on this side of the rainbow now, / where the world is generous with itself". The collection's preoccupation with space and place is reflected in the way that the township and the urban spaces are juxtaposed against each other in this poem. Furthermore, the poem hints at the ways in which access to 
capital leads to command of a kind of cultural capital that can obscure the speaker's history of hardship:

I sit at the table with people who don't know leaking roofs

and the waiter hands each of us the same menu.

From my office window I see cars speeding on the highway

and think how awesome it would be, brother,

to drive with our arms stretched out like wings,

the air fanning us,

brushing against our black skin-

who would tell that I left you a dining room floor to sleep on?

These poems for Zamo speak of the visceral experience of poverty, which is linked explicitly to race-one of the many damaging legacies of apartheid. The knowledge of those circumstances continually informs the speaker's experience of the world.

The speaker, who must negotiate radically discordant worlds, adopts a marked shift in point of view, from first-person to third-person, in the final section of the collection, where his "Urban" experiences are recorded. Khanyile's minimalist vignettes create the illusion of transparency, and the reader appears to get unmediated access to the experiences of the single, autobiographical speaker. When shifts in point of view thus do occur, the reader is particularly aware of the distancing effect.

In the poem "Emptiness" (46-7) for example, the third-person point of view is used to reflect on the speaker's worries

[...] about silly things.

Even about his English which runs out like airtime while he speaks.

He's ashamed of everything,

including the master's degree that he obtained from a rural university

which sits at the bottom of the list.

Now he's at a top university where they needed the colour of his skin

to push their agenda of transformation.

This poem again foregrounds the enduring link between poverty and race in South Africa, and points to the kind of psychological and emotional damage that living in these circumstances inflicts on the psyche. As in "A School Visit", we note here the speaker's sense of inadequacy about his comportment, his background and his credentials. His existential emptiness is mir- rored by the space of his flat, "that only has a bed and a barstool" (47).

The last poem in the collection, "When You Finally Make It Into The Boardroom" (55), is addressed to a "you", and reads as a series of suggestions for how to talk about growing up in the township. The poem registers the dissonance between the two worlds of the boardroom and the township. The reader is advised to "Speak of growing up in the township as if it was an achievement. / Say that it was because you made it out alive". The speaker tells the reader to "Correct those who ask you: What was it like growing up in the township? / Say the appropriate question is: How did you survive the township?" (emphasis in original). This advice sets up the parameters within which one is expected to talk about growing up in the township. There are also restrictions: "Wall in the tears. Keep tears to yourself". This line introduces the notion of repression, and how repression functions in this particular narrative of self.

The poem continues to play off this idea of repression by listing the things that you can and cannot speak about in the boardroom: talk about the mother "who prayed for you on your way to school", but keep to yourself the thoughts of "those from the same block who amounted to nothing" and "street corners where bodies lay bloodied and cold". At the end, the reader is told:

Be the first one to say: None of that matters anymore.

Gobble down a glass of water.

Move on to another topic.

The disjuncture between external and internal-between what the speaker thinks and what he sayshighlights the immense distance that the speaker must attempt to breach between the township and the boardroom. In my reading, the poem comprises a series of rules on etiquette, designed to protect the boardroom audience from the full knowledge of the township experiences that still haunt the speaker. In this way, the collection ends with a device that asks the reader to confront their own expectations of the speaker and those whom he represents, like the little girl in the rural school who dreams of being a doctor.

\author{
Annel Helena Pieterse \\ annel.pieterse@gmail.com \\ Stellenbosch University \\ Stellenbosch \\ ORCID: https://orcid.org/0000-0003-1 $117-1043$
}

DOI: https://doi.org/10.17159/2309-9070/tvl.v.57il.7832 